\title{
The 3/4- and 3/6-Subfamily Variants of $\alpha$-Conotoxins GI and MI Exhibit Potent Inhibitory Activity against Muscular Nicotinic Acetylcholine Receptors
}

\author{
Xiaoli Ma ${ }^{1,2, \dagger}$, Qiuyuan Huang ${ }^{1,+}$, Shuo $\mathrm{Yu}^{1}{ }^{1}$, Shujing Xu ${ }^{1}$, Yue Huang ${ }^{1}$, Zhiming Zhao ${ }^{1}$, Xinrong Xiao ${ }^{2, *}$ \\ and Qiuyun Dai ${ }^{1, *}$ \\ 1 Beijing Institute of Biotechnology, Beijing 100071, China; maxiaoli775621363@163.com (X.M.); \\ huangqy654678@163.com (Q.H.); o_yys@163.com (S.Y.); xushujing0225@163.com (S.X.); \\ vayuuuu@163.com (Y.H.); 13679460257@163.com (Z.Z.) \\ 2 Institute of Chemistry and Chemical Engineering, University of South China, Henyang 421000, China \\ * Correspondence: $986000796 @ u s c . e d u . c n(X . X$.$) ; daiqy@bmi.ac.cn (Q.D.); Tel.: +86-10-6694-8897 (Q.D.)$ \\ + These authors contributed equally.
}

Citation: Ma, X.; Huang, Q.; Yu, S.; Xu, S.; Huang, Y.; Zhao, Z.; Xiao, X.; Dai, Q. The 3/4- and 3/6-Subfamily Variants of $\alpha$-Conotoxins GI and MI Exhibit Potent Inhibitory Activity against Muscular Nicotinic Acetylcholine Receptors. Mar. Drugs 2021, 19, 705. https://doi.org/ $10.3390 /$ md19120705

Academic Editors: Himaya Siddhihalu Wickrama Hewage and Jean Jin

Received: 3 November 2021

Accepted: 3 December 2021

Published: 14 December 2021

Publisher's Note: MDPI stays neutral with regard to jurisdictional claims in published maps and institutional affiliations.

Copyright: (c) 2021 by the authors. Licensee MDPI, Basel, Switzerland. This article is an open access article distributed under the terms and conditions of the Creative Commons Attribution (CC BY) license (https:// creativecommons.org/licenses/by/ $4.0 /)$.
Abstract: $\alpha$-Conotoxins GI and MI belong to the $3 / 5$ subfamily of $\alpha$-conotoxins and potently inhibit muscular nicotinic acetylcholine receptors (nAChRs). To date, no 3/4- or 3/6-subfamily $\alpha$-conotoxins have been reported to inhibit muscular nAChRs. In the present study, a series of new 3/4-, 3/6-, and 3/7-subfamily GI and MI variants were synthesized and functionally characterized by modifications of loop2. The results show that the 3/4-subfamily GI variant GI[ $\Delta 8 \mathrm{G}]-\mathrm{II}$ and the 3/6-subfamily variants GI[+13A], GI[+13R], and GI[+13K] displayed potent inhibition of muscular nAChRs expressed in Xenopus oocytes, with an $\mathrm{IC}_{50}$ of 45.4-73.4 nM, similar to or slightly lower than that of wild-type GI (42.0 nM). The toxicity of these GI variants in mice appeared to be about a half to a quarter of that of wild-type GI. At the same time, the 3/7-subfamily GI variants showed significantly lower in vitro potency and toxicity. On the other hand, similar to the 3/6-subfamily GI variants, the 3/6-subfamily MI variants $\mathrm{MI}[+14 \mathrm{R}]$ and $\mathrm{MI}[+14 \mathrm{~K}]$ were also active after the addition of a basic amino acid, Arg or Lys, in loop2, but the activity was not maintained for the 3/4-subfamily MI variant $\mathrm{MI}[\Delta 9 \mathrm{G}]$. Interestingly, the disulfide bond connectivity "C1-C4, C2-C3" in the 3/4-subfamily variant $\mathrm{GI}[\Delta 8 \mathrm{G}]-\mathrm{II}$ was significantly more potent than the "C1-C3, C2-C4" connectivity found in wild-type GI and MI, suggesting that disulfide bond connectivity is easily affected in the rigid 3/4-subfamily $\alpha$-conotoxins and that the disulfide bonds significantly impact the variants' function. This work is the first to demonstrate that 3/4- and 3/6-subfamily $\alpha$-conotoxins potently inhibit muscular nAChRs, expanding our knowledge of $\alpha$-conotoxins and providing new motifs for their further modifications.

Keywords: $\alpha$-conotoxins GI and MI; muscular nicotinic acetylcholine receptors; subfamily variants; structure-activity relationship

\section{Introduction}

Nicotinic acetylcholine receptors (nAChRs) are a class of ligand-gated ion channel protein receptors that mediate rapid signal transmission between synapses [1,2]. They are widely distributed in the central and peripheral nervous systems and muscles [3]. nAChRs are divided into two types: neuronal type and muscular type [3,4]. Neuronal nAChRs contain multiple different subunits, namely, $\alpha 2-\alpha 7, \alpha 9, \alpha 10$, and $\beta 2-\beta 4$, which constitute homopentamers or heteropentamers. Muscular nAChRs are composed of $\alpha 1, \beta 1, \gamma, \delta$, or $\varepsilon$ subunits, and different subtypes of $\mathrm{nAChRs}$ mediate different pathophysiological functions [5]. Neuronal nAChRs are associated with a series of central nervous system dysfunctions, including pain, addiction, epilepsy, Alzheimer's disease, Parkinson's disease, and schizophrenia [6-8], while muscular nAChRs are associated with physiological functions (such as muscular movement and signal transmission) and pathophysiological 
conditions [1,5], including pain, myogenic diseases, muscular dystrophy, and myasthenia gravis.

$\alpha$-Conotoxins are small peptides composed of 12-20 amino acids, containing two pairs of disulfide bonds with a main globular disulfide bond framework " $\mathrm{C} 1-\mathrm{C} 3, \mathrm{C} 2-\mathrm{C} 4$ " [9-11]. The general structural formula of $\alpha$-conotoxins is -CC-(loop 1)-C-(loop 2)-C- [1]. According to the number of residues in loop 1 and loop $2, \alpha$-conotoxins can be further divided into several structural subfamilies such as $3 / 5,4 / 3,4 / 4,4 / 5,4 / 6$, and $4 / 7$ subfamilies [12-14]. They are potent antagonists of nAChRs, and studies on structure-activity relationship have shown that the loop 1 of $\alpha$-conotoxins plays a key role in the selectivity of nAChR types $[9,13]$ and the number of amino acids in loop1 has little effect on loop1 structure. On the other hand, the loop 2 of $\alpha$-conotoxins plays a key role in the inhibitory activity and selectivity of nAChR subtypes [11,15]. In general, the $3 / 5$ subfamily of $\alpha$-conotoxins mainly target fish or mammalian neuromuscular nAChRs; typical toxin members include GI [16-19], MI [20,21], GII [22], GIA [22], SIA [23], SI [24,25], CnIA [26], CIA [27], CIB [27], and MilIA [28]. A number of other conotoxins have also been found to act on neuromuscular nAChRs, such as EI [29], PIVA [30], OIVA [31], OIVB [32], PIB [33], EIVA [34], EIIA [35], PIC [36], and MIIIJ [37]. On the other hand, 4/3, 4/4, 4/5, 4/6, and 4/7 $\alpha$-conotoxins usually target neuronal nAChRs $[11,13]$. Among the conotoxins reported, GI and MI are the most potent. To date, no 3/4-, 3/6-, and 3/7-subfamily $\alpha$-conotoxins have been reported.

In order to discover new subfamilies of $\alpha$-conotoxins targeting muscular nAChRs and provide new pharmacological probe molecules, in the present study, a series of 3/4-, $3 / 6-$, and 3/7-subfamily variants of $\alpha$-conotoxins GI and MI were synthesized, and their inhibitory activities against muscular nAChRs and toxicity in mice were determined. Surprisingly, it was found that with the deletion of the first amino acid Gly in loop2 of GI, the generated linear peptide variant, GI[ $\Delta 8 \mathrm{G}]-\mathrm{II}$, mainly folded with the disulfide bond connection " $\mathrm{C} 1-\mathrm{C} 4, \mathrm{C} 2-\mathrm{C} 3$ " instead of the wild-type "C1-C3, C2-C4" connection. The 3/4subfamily variant GI[ $\Delta 8 \mathrm{G}]-\mathrm{II}$ and the 3/6-subfamily variants GI[+13A], GI[+13R], GI[+13K] displayed high potency in inhibiting muscular nAChRs, with a $\mathrm{IC}_{50}$ of $45.4-73.4 \mathrm{nM}$, comparable to or slightly lower than that of wild-type GI $(42.0 \mathrm{nM})$, while the toxicity in mice was about a half to a quarter of that of wild-type GI. The 3/7-subfamily GI variants showed significantly lower potency in vitro and toxicity in vivo compared to wild-type GI. In addition, 3/4-, 3/6-, and 3/7-subfamily MI variants were investigated, and the on-rate and off-rate kinetics of inhibition of muscular nAChRs by GI, MI, and their variants were also determined. This work is the first to identify the inhibitory functions of 3/4- and $3 / 6$-subfamily $\alpha$-conotoxins towards muscular nAChRs. This expands our knowledge of $\alpha$-conotoxins and provides new motifs for their further modifications.

\section{Results}

\subsection{Synthesis and Characterization of Conotoxins}

A series of 3/4-, 3/6-, and 3/7-subfamily variants of $\alpha$-conotoxins GI and MI were designed and synthesized (Table 1). Linear GI, MI, and their variants were folded individually in $0.1 \mathrm{mM}$ ammonium acetate buffer and analyzed by HPLC. The analytical results of the typical folding products of GI[ $\Delta 8 \mathrm{G}]-\mathrm{II}, \mathrm{GI}[+13 \mathrm{~K}], \mathrm{GI}[+13 \mathrm{~K},+14 \mathrm{~A}]$ and GI$[+13 \mathrm{G},+14 \mathrm{G}]$ are shown in Figure 1. All variants showed a main peak, and the purity was $>95 \%$ after purification. Their molecular weight was determined by ProFLEXTM-III MALDI-TOF mass spectrometry and was consistent with the theoretical molecular weight (Table 1). 
Table 1. Amino acid sequence and inhibitory activities of GI and MI and their variants with respect to muscular nAChRs.

\begin{tabular}{|c|c|c|c|c|}
\hline NO. & Name & Amino Acid Sequences & $\begin{array}{c}\text { Theoretical MW } \\
\text { (Experimental) (Da) }\end{array}$ & $\begin{array}{c}\mathrm{IC}_{50}(\mathrm{nM})(95 \%) \\
\text { Confidence Intervals }\end{array}$ \\
\hline & GI & ECCNPACGRHYSC * & $1436.52(1437.49)$ & $42.0(38.8-45.4)$ \\
\hline 1 & $\mathrm{GI}[\Delta 8 \mathrm{G}]-\mathrm{I}^{\mathrm{a}}$ & ECCNPACRHYSC * & $1379.49(1380.46)$ & $248.1(221.3-275.9)$ \\
\hline 2 & $\mathrm{GI}[\Delta 8 \mathrm{G}]-\mathrm{II}{ }^{\mathrm{b}}$ & ECCNPACRHYSC * & $1379.49(1380.41)$ & $50.4(45.9-55.4)$ \\
\hline 3 & $\mathrm{GI}[+13 \mathrm{G}]$ & ECCNPACGRHYSGC * & $1493.54(1493.51)$ & $>200$ \\
\hline 4 & $\mathrm{GI}[+13 \mathrm{~A}]$ & ECCNPACGRHYSAC * & 1507.55 (1508.47) & $45.4(41.7-49.3)$ \\
\hline 5 & $\mathrm{GI}[+13 \mathrm{R}]$ & ECCNPACGRHYSRC * & $1592.62(1593.51)$ & $73.5(69.2-78.1)$ \\
\hline 6 & $\mathrm{GI}[+13 \mathrm{~K}]$ & ECCNPACGRHYSKC ${ }^{*}$ & $1564.61(1565.50)$ & $47.7(44.2-51.5)$ \\
\hline 7 & $\mathrm{GI}[+13 \mathrm{G},+14 \mathrm{G}]$ & ECCNPACGRHYSGGC * & $1550.56(1551.48)$ & $>200$ \\
\hline 8 & $\mathrm{GI}[+13 \mathrm{~K},+14 \mathrm{~A}]$ & ECCNPACGRHYS $\underline{K A}$ C * & $1635.65(1636.54)$ & $>500$ \\
\hline \multirow[t]{2}{*}{9} & $\mathrm{GI}[+13 \mathrm{~A},+14 \mathrm{~K}]$ & ECCNPACGRHYS $\underline{A K C}$ * & $1635.65(1636.54)$ & $>500$ \\
\hline & MI & GRCCHPACGKNYSC * & $1492.59(1439.38)$ & $7.0(5.6-8.8)$ \\
\hline 10 & $\mathrm{MI}[\Delta 9 \mathrm{G}]$ & GRCCHPACKNYSC * & $1435.57(1436.46)$ & $>500$ \\
\hline 11 & $\mathrm{MI}[+14 \mathrm{~A}]$ & GRCCHPACGKNYSAC * & $1563.63(1564.52)$ & $>200$ \\
\hline 12 & $\mathrm{MI}[+14 \mathrm{R}]$ & GRCCHPACGKNYSRC * & $1648.69(1649.58)$ & $22.2(19.8-25.1)$ \\
\hline 13 & $\mathrm{MI}[+14 \mathrm{~K}]$ & GRCCHPACGKNYSKC * & $1620.68(1621.58)$ & $62.7(57.9-67.9)$ \\
\hline 14 & $\mathrm{MI}[+14 \mathrm{~K},+15 \mathrm{~A}]$ & GRCCHPACGKNYSKAC * & $1691.72(1692.61)$ & $>500$ \\
\hline 15 & $\mathrm{MI}[+14 \mathrm{R},+15 \mathrm{~A}]$ & GRCCHPACGKNYS $\underline{R A C}$ * & $1719.73(1720.62)$ & $>500$ \\
\hline
\end{tabular}

a , GI[ $\Delta 8 \mathrm{G}]-$ I contains a disulfide bridge "1-3, 2-4"; ${ }^{\mathrm{b}}, \mathrm{GI}[\Delta 8 \mathrm{G}]-\mathrm{II}$ contains a disulfide bridge "1-4, 2-3"; *, C-terminus is amidated.



Retention time (min)

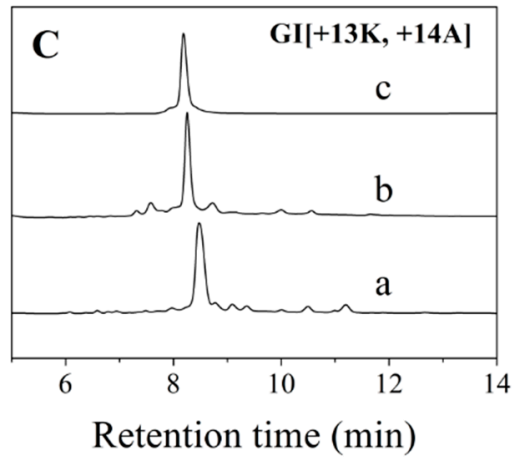

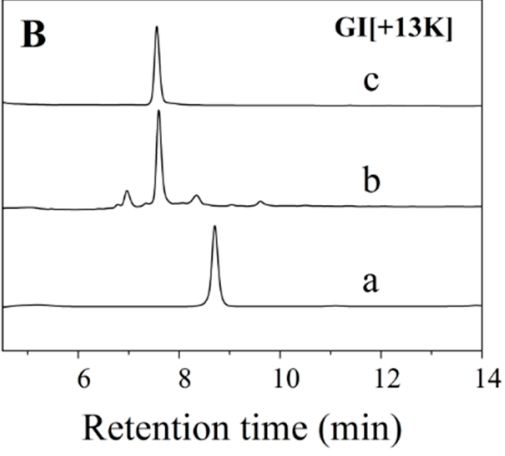

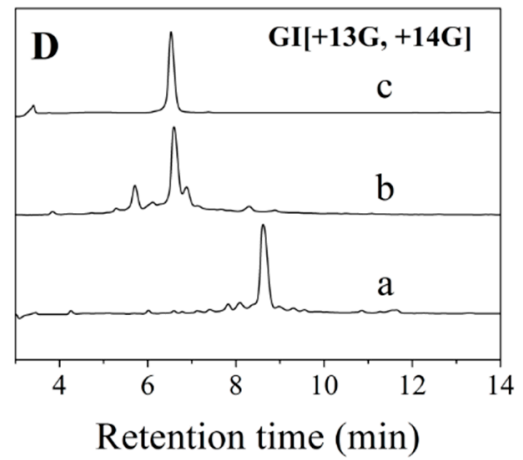

Figure 1. HPLC analyses of one-step folding products of linear GI variants. (A) GI[ $\Delta \mathrm{G} 8]$-II. (B) GI[+13K]. (C) GI[+13K, +14A]. (D) GI[+13G, +14G].Traces from bottom to top: linear peptide (a), folded products (b), purified products (c). Samples were applied to an Agilent Eclipse Plus C18 column $(5 \mu \mathrm{m}, 4.6 \mathrm{~mm} \times 250 \mathrm{~mm})$ and eluted with a linear gradient of $5-10 \%$ B for $0-1 \mathrm{~min} ; 10-50 \% \mathrm{~B}$ ( $\mathrm{B}$ is acetonitrile containing $0.1 \%$ trifluoroacetic acid (TFA)) for 1-25 min. Absorbance was monitored at $214 \mathrm{~nm}$. Flow rate was $1.0 \mathrm{~mL} / \mathrm{min}$.

\subsection{Disulfide Bond Connectivity}

The first folding of the GI[ $\triangle 8 \mathrm{G}]-\mathrm{I}[\mathrm{EC}(\mathrm{Acm}) \mathrm{CNPAC}(\mathrm{Acm}) \mathrm{RHYSC}]$ linear peptide modified by Acm at position 1,3 formed a product containing a "C2-C4" disulfide bond (Figure 
2A). After the Acm protecting group was removed by iodine oxidation, the main product containing disulfide bond connectivity " $\mathrm{C} 1-\mathrm{C} 3, \mathrm{C} 2-\mathrm{C} 4$ " formed (Figure $2 \mathrm{~A}(\mathrm{c})$ ). On the other hand, for GI[ $\Delta 8 \mathrm{G}]-\mathrm{II}$, the mixture of the two-step folding product (GI[ $\Delta 8 \mathrm{G}]-\mathrm{I})$ and the one-step folding product showed two peaks, indicating the disulfide bond connectivity of the one-step folding product was not " $\mathrm{C} 1-\mathrm{C} 3, \mathrm{C} 2-\mathrm{C} 4$ ". The final folded product of Acm-modified GI[ $\Delta 8 \mathrm{G}]-\mathrm{II}$ at "C1, C4" showed a single peak when it was mixed with the one-step folding product (Figure $2 \mathrm{~B}$ ), indicating its disulfide bond connectivity was "C1-C4, C2-C3". Using a similar method, the disulfide bond connectivity of the one-step folding products of $\mathrm{GI}[+13 \mathrm{~K}], \mathrm{GI}[+13 \mathrm{G},+14 \mathrm{G}]$, and $\mathrm{MI}[\Delta 9 \mathrm{G}]$ were also determined. The results demonstrated that these variants have the same disulfide bond connectivity " $\mathrm{C} 1-\mathrm{C} 3$, C2-C4" as those of wild-type GI and MI (Figure 2C-F).
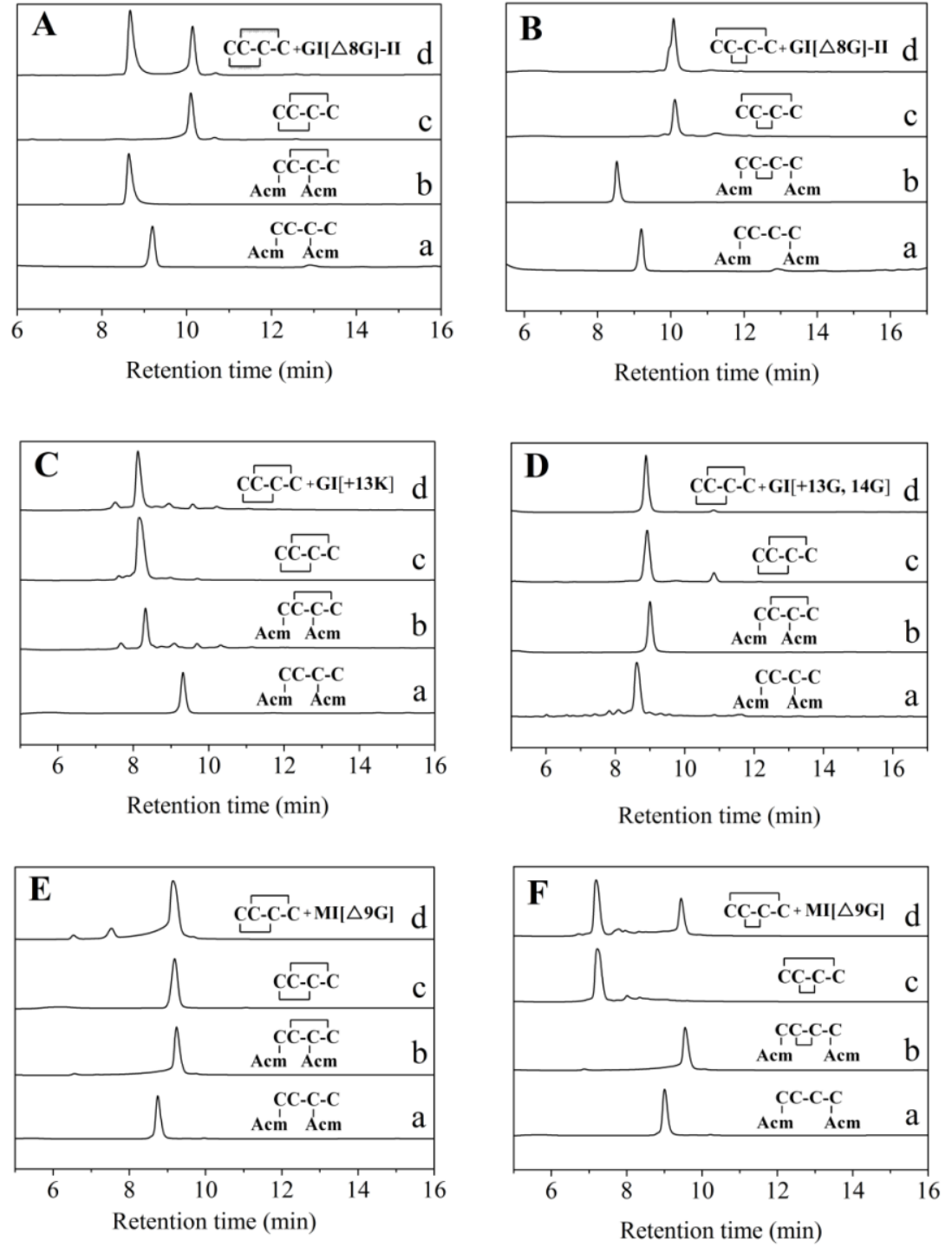

Figure 2. HPLC analyses of the folded products of linear GI and MI variants with Acm modification. (A) Linear GI[ $\Delta 8 \mathrm{G}]-$ I with Acm modifications at Cys1 and Cys3. (B) Linear GI[ $\Delta 8 \mathrm{G}]-\mathrm{II}$ with Acm modifications at Cys1 and Cys4. (C) Linear GI[+13K] with Acm modifications at Cys1 and Cys3. (D) Linear GI[+13G, +14G] with Acm modifications at Cys1 and Cys3. (E) Linear MI[ $\Delta 9 \mathrm{G}]-\mathrm{I}$ with Acm modifications at Cys1 and Cys3. (F) Linear MI[ $\Delta 9 \mathrm{G}]-\mathrm{II}$ with Acm modifications at Cys1 and Cys4. Traces from bottom to top: linear peptide (a), primary oxidized product (b), secondary oxidized product (c), and co-elution of the two-step folding product and one-step natural-air folding oxidation product (d). HPLC analysis conditions are the same as in Figure 1. 


\subsection{Circular Dichroism (CD) Spectroscopy}

CD spectra (Figure 3) of the GI and MI variants showed that wild-type GI and MI have a certain number of $\alpha$-helices because they exhibit negative peaks at 222 and 208 $\mathrm{nm}$, consistent with their NMR structures [38,39]. However, after the addition of one or two amino acids in loop 2, the $\alpha$-helix content of the variants, such as GI[+13R], GI[+13K], $\mathrm{GI}[+13 \mathrm{~A}], \mathrm{GI}[+13 \mathrm{~K},+14 \mathrm{~A}], \mathrm{GI}[+13 \mathrm{G},+14 \mathrm{G}], \mathrm{MI}[+14 \mathrm{R}], \mathrm{MI}[+14 \mathrm{~K}], \mathrm{MI}[+14 \mathrm{~K},+15 \mathrm{~A}]$, was significantly reduced. Some variants only exhibited a negative peak near $198 \mathrm{~nm}$, indicating a random coil structure. GI[ $\Delta \mathrm{G} 8]-\mathrm{II}$ appeared to have almost a random coil structure because its disulfide bond connectivity was " $1-4,2-3$ ", but the CD spectrum of MI[ $\Delta 9 \mathrm{G}]$ was similar to that of MI.

A

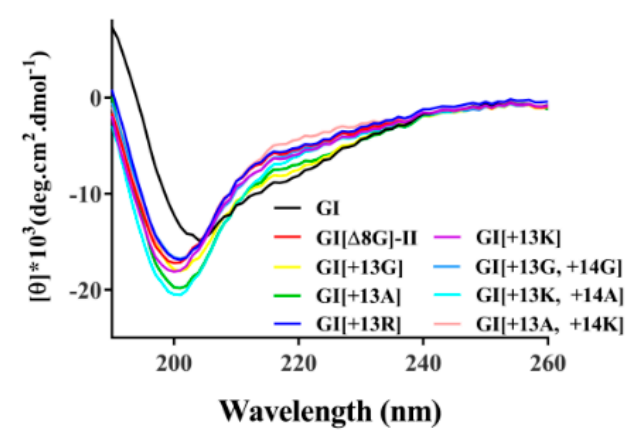

B

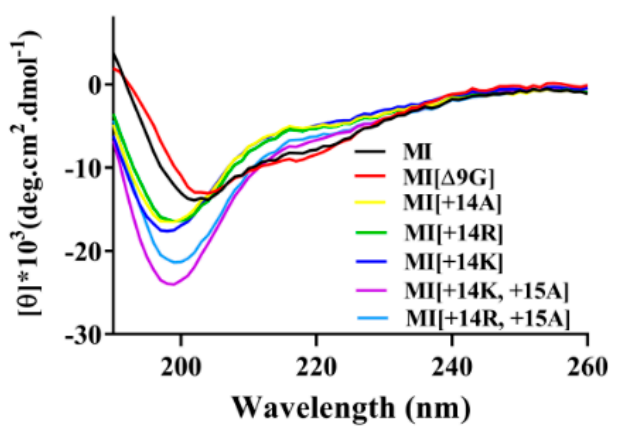

Figure 3. Circular dichroism spectra of $\alpha$-conotoxins and their variants in $0.01 \mathrm{M}$ PBS (pH = 7.2). (A) GI mutants. (B) MI mutants. $n=3$.

\subsection{Inhibitory Activity of $\alpha$-Conotoxins GI and MI Variants against Muscular nAChRs}

The inhibitory activity of GI and MI variants toward muscular nAChRs expressed in Xenopus oocytes was determined. The results showed that wild-type GI exhibited a strong inhibition of the rat muscular $\mathrm{nAChR}$, with an $\mathrm{IC}_{50}$ of $42.0 \mathrm{nM}$ (Figure 4 and Table 1). After the deletion of Gly in loop2, the inhibitory activity of GI[ $\Delta 8 \mathrm{G}]$-II decreased slightly $\left(\mathrm{IC}_{50}=50.4 \mathrm{nM}\right)$, which is in contrast with what observed for the disulfide bond isomer GI[ $\Delta 8 \mathrm{G}]-\mathrm{I}$ : the latter displayed lower potency $\left(\mathrm{IC}_{50}=248.1 \mathrm{nM}\right)$, nearly a four-fold decrease compared to the wild-type. After the addition of one amino acid residue in loop 2 (such as Ala, Lys, and Arg), the $\mathrm{IC}_{50}$ values changed to $45.4 \mathrm{nM}, 47.5 \mathrm{nM}$, and $73.5 \mathrm{nM}$ for the 3/6-subfamily variants GI[+13A], GI[+13K], and GI[+13R], respectively, comparable to or slightly lower than the values of wild-type GI at $42.0 \mathrm{nM}$. However, the addition of two residues (GG or KA or AK) in loop2 resulted in a sharp decrease in potency $\left(\mathrm{IC}_{50}>200 \mathrm{nM}\right)$. Similar modifications were performed for MI. The results showed that wild-type MI potently inhibited the muscle-type nAChRs, with an $\mathrm{IC}_{50}$ of $7.0 \mathrm{nM}$, but differently from what observed for GI[ $\Delta 8 \mathrm{G}]$, with the deletion of Gly9 in loop2, MI[ $\Delta 9 \mathrm{G}]$ became inactive $\left(\mathrm{IC}_{50}>500 \mathrm{nM}\right)$, despite possessing the same disulfide bond connectivity as wild-type MI. Similar to the GI variants, the 3/6-subfamily MI[+14R] and MI[+14K] variants were also active after the addition of the basic amino acids Arg or Lys at loop2, while the 3/7-subfamily variants of MI lacked inhibitory activity $\left(\mathrm{IC}_{50}>500 \mathrm{nM}\right)$. 
A

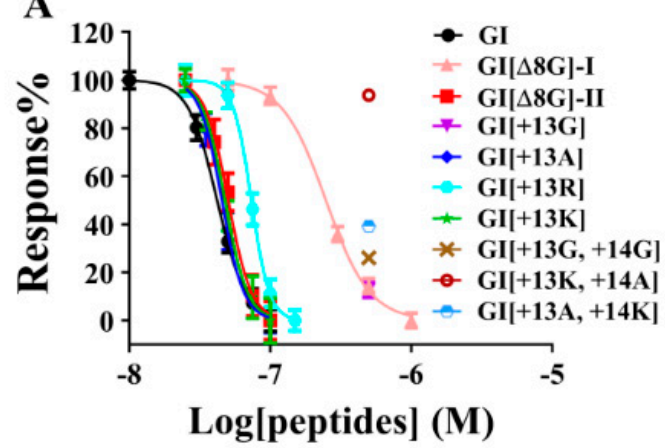

B



Figure 4. Concentration-dependent response curves of the GI and MI variants interacting with rat muscular nAChRs. (A) GI variants; (B) MI variants. The error bars for the data denote the SEM. Five to seven oocytes were used for each determination. The $\mathrm{IC}_{50}$ values and $95 \%$ confidence intervals are summarized in Table 1.

\subsection{On-Rate and Off-Rate Kinetics for $\alpha$-Conotoxins GI and MI Variants Interacting with Muscular nAChRs}

The on-rate and off-rate kinetics of GI, MI, and their variants with a high potency interacting with muscular nAChRs were determined (Figure 5, Table 2). After wild-type GI $(100 \mathrm{nM})$ bound to muscular nAChRs, the time for $50 \%$ recovery $\left(t_{1 / 2}\right)$ of nAChRs was $4.26 \mathrm{~min}$. Compared to wild-type GI, the dissociation rates of GI[ $\Delta 8 \mathrm{G}]-\mathrm{II}$ and GI[+13A] were slower, with $t_{1 / 2}$ at $6.63 \mathrm{~min}$ and $7.04 \mathrm{~min}$, respectively, but the corresponding recovery rates of GI[ $\Delta 8 \mathrm{G}]-\mathrm{II}(85.9 \%)$ and GI[+13A] $(81.9 \%)$ were significantly higher than that of GI (44.9\%) at $24 \mathrm{~min}$. Accordingly, the inhibition constants $\left(K_{i}\right)$ of GI[ $\left.\Delta 8 \mathrm{G}\right]-\mathrm{II}$ and $\mathrm{GI}[+13 \mathrm{~A}]$ were $125.0 \mathrm{M}^{-9}$ and $76.92 \mathrm{M}^{-9}$, lower than that of wild-type GI $\left(48.48 \mathrm{M}^{-9}\right)$. The addition of amino acids in MI resulted in a similar behavior of MI[+14R], which had a higher inhibition constant $K i$ compared to wild-type MI, but more easily dissociated from $\mathrm{nAChRs}$, and displayed a lower $t_{1 / 2}(3.78 \mathrm{~min})$ than wild-type $\mathrm{MI}\left(t_{1 / 2}=9.82 \mathrm{~min}\right)$. These results demonstrated that GI $\Delta 8 \mathrm{G}]-\mathrm{II}, \mathrm{GI}[+13 \mathrm{~A}]$, and $\mathrm{MI}[+14 \mathrm{R}]$ dissociate more easily from nAChRs compared to their wild-type counterparts.

\subsection{Toxicity of GI and MI Variants in Mice}

The toxicity of GI and MI variants was determined in mice (Table 3). The doses of wild-type GI and MI were 40 and $20 \mu \mathrm{g} / \mathrm{kg}$, which resulted in $90-100 \%$ mortality in mice. The 3/4-subfamily GI variant GI[ $\Delta 8 \mathrm{G}]-$ II exhibited medium toxicity, with dose levels of $80,120,160 \mu \mathrm{g} / \mathrm{kg}$ leading to death rates of 0,60 , and $80 \%$, which were around four-fold lower than that of GI at the corresponding dose. After the addition of one basic amino acid residue (such as Arg and Lys) in loop2 of GI, the toxicity did not decrease as dramatically. The doses of 80 and $120 \mu \mathrm{g} / \mathrm{kg}$ of GI[+13R] and GI[+13K] resulted in a death rate of $80-100 \%$, which indicated a toxicity around two-fold lower than that of wild-type GI. In contrast, adding alanine and glycine to loop2 significantly decreased the toxicity, with $120 \mu \mathrm{g} / \mathrm{kg}$ or higher of GI[+13A] and GI[+13G] required to induce obvious death in mice. The 3/7-subfamily GI variants generally displayed low toxicity: GI[+13A, $+14 \mathrm{~K}]$ exhibited similar toxicity to GI[+13G], while the toxicity of $\mathrm{GI}[+13 \mathrm{~K},+14 \mathrm{~A}]$ and $\mathrm{GI}[+13 \mathrm{G},+14 \mathrm{G}]$ were almost lost $(200 \mu \mathrm{g} / \mathrm{kg}$ resulted in no death).

For the MI variants, the 3/4-, 3/6-, and 3/7-subfamily MI variants displayed dramatically decreased toxicity, with the most toxic MI $[+14 \mathrm{~K}]$ leading to a mortality rate of only $20 \%$ at a high dose of $200 \mu \mathrm{g} / \mathrm{kg}$, while all other MI variants did not induce any death even at $200 \mu \mathrm{g} / \mathrm{kg}$. 




Figure 5. Kinetic analyses of GI and MI variants interacting with Xenopus oocyte-expressed rat muscular nAChRs. (A) GI, (B) GI[ $\Delta 8 \mathrm{G}]$, (C) GI[+13A] (D) MI, (E) MI[+14R]. The toxins were applied as described in Materials and Methods, and the data were fit to a single exponential equation. The error bars denote the SEM of the data obtained using four to seven oocytes for each determination. The kinetic data are summarized in Table 2.

Table 2. Kinetic analysis of the onset and recovery from inhibition of muscular nAChRs.

\begin{tabular}{|c|c|c|c|c|c|}
\hline \multirow{2}{*}{$\alpha-\mathrm{CTX}$} & $k_{\text {off }}$ & $t_{1 / 2}{ }^{a}$ & $k_{\mathrm{obs}} \mathrm{b}$ & $k_{\text {on }}$ & $K_{\mathrm{i}}^{\mathrm{c}}$ \\
\hline & $\min ^{-1}$ & $\min$ & $\min ^{-1}$ & $\min ^{-1} \mathbf{M}^{-1}$ & $\mathbf{M}^{-9}$ \\
\hline GI & $0.16 \pm 0.03$ & $4.26(3.16-6.54)$ & $0.49 \pm 0.02$ & $0.33 \times 10^{7}$ & 48.48 \\
\hline $\mathrm{GI}[\Delta 8 \mathrm{G}]-\mathrm{II}$ & $0.10 \pm 0.01$ & $6.63(5.25-8.99)$ & $0.18 \pm 0.01$ & $0.08 \times 10^{7}$ & 125.0 \\
\hline $\mathrm{GI}[+13 \mathrm{~A}]$ & $0.10 \pm 0.02$ & 7.04 (5.26-10.65) & $0.23 \pm 0.02$ & $0.13 \times 10^{7}$ & 76.92 \\
\hline MI & $0.07 \pm 0.01$ & 9.82 (7.67-13.67) & $1.92 \pm 0.31$ & $1.85 \times 10^{7}$ & 3.78 \\
\hline $\mathrm{MI}[+14 \mathrm{R}]$ & $0.18 \pm 0.02$ & $3.78(3.12-4.80)$ & $1.40 \pm 0.31$ & $1.22 \times 10^{7}$ & 14.75 \\
\hline
\end{tabular}

${ }^{\mathrm{a}}: t_{1 / 2}=0.693 / k_{o f f} ;{ }^{\mathrm{b}}: k_{o b s}=k_{\text {on }}\left[\right.$ toxin] $+k_{o f f} ; \mathrm{c}: K i=k_{o f f} / k_{\text {on }} ; t_{1 / 2}$ is the time required for a $50 \%$ dissociation of conotoxins from muscular $n A C h R s, k_{o n}$ is the association rate constant, $K i$ is the inhibition constant; data are means \pm SEM from experiments with five-eight oocytes. Numbers in parentheses indicate the $95 \%$ confidence intervals. 
Table 3. Toxicity of $\alpha$-conotoxins GI and MI variants in mice.

\begin{tabular}{|c|c|c|c|c|c|c|c|c|c|c|c|c|}
\hline \multirow{2}{*}{$\begin{array}{l}\alpha \text {-Conotoxins GI } \\
\text { and MI Variant }\end{array}$} & \multicolumn{2}{|c|}{$20 \mu \mathrm{g} / \mathrm{kg}$} & \multicolumn{2}{|c|}{$40 \mu \mathrm{g} / \mathrm{kg}$} & \multicolumn{2}{|c|}{$80 \mu \mathrm{g} / \mathrm{kg}$} & \multicolumn{2}{|c|}{$120 \mu \mathrm{g} / \mathrm{kg}$} & \multicolumn{2}{|c|}{$160 \mu \mathrm{g} / \mathrm{kg}$} & \multicolumn{2}{|c|}{$200 \mu \mathrm{g} / \mathrm{kg}$} \\
\hline & Death Time (s) & $\begin{array}{c}\text { Death } \\
\text { Rate (\%) }\end{array}$ & Death Time (s) & $\begin{array}{c}\text { Death } \\
\text { Rate (\%) }\end{array}$ & Death Time (s) & $\begin{array}{c}\text { Death } \\
\text { Rate (\%) }\end{array}$ & Death Time (s) & $\begin{array}{c}\text { Death } \\
\text { Rate (\%) }\end{array}$ & Death Time (s) & $\begin{array}{c}\text { Death } \\
\text { Rate (\%) }\end{array}$ & Death Time (s) & $\begin{array}{c}\text { Death } \\
\text { Rate (\%) }\end{array}$ \\
\hline GI & & 0 & $1075.3 \pm 150.5$ & 100 & & & & & & & & \\
\hline $\mathrm{GI}[+13 \mathrm{G}]$ & & & & & & & $1036.6 \pm 215.6$ & 30 & & & $610.5 \pm 239.6$ & 90 \\
\hline $\mathrm{GI}[+13 \mathrm{~A}]$ & & & & & & & 0 & 0 & & & $1356.1 \pm 41.1$ & 20 \\
\hline $\mathrm{GI}[+13 \mathrm{R}]$ & & & 0 & 0 & $1441.5 \pm 231.0$ & 80 & $929.2 \pm 297.3$ & 90 & $704.5 \pm 57.6$ & 100 & & \\
\hline $\mathrm{GI}[+13 \mathrm{~K}]$ & & & 1619 & 10 & $1199.9 \pm 383.4$ & 90 & $771.3 \pm 96.8$ & 100 & & & & \\
\hline $\mathrm{GI}[+13 \mathrm{G},+14 \mathrm{G}]$ & & & & & & & & & & & 0 & 0 \\
\hline $\mathrm{GI}[+13 \mathrm{~A},+14 \mathrm{~K}]$ & & & & & 0 & 0 & 0 & 0 & & & $1107.2 \pm 250.3$ & 100 \\
\hline MI & $1185.7 \pm 167.5$ & 100 & & & & & & & & & & \\
\hline $\mathrm{MI}[\Delta 9 \mathrm{G}]$ & & & & & & & & & & & 0 & 0 \\
\hline $\mathrm{MI}[+14 \mathrm{~A}]$ & & & & & & & & & & & 0 & 0 \\
\hline $\mathrm{MI}[+14 \mathrm{R}]$ & & & & & & & & & & & 0 & 0 \\
\hline $\mathrm{MI}[+14 \mathrm{~K}]$ & & & & & & & 0 & 0 & & & $895.5 \pm 383.9$ & 20 \\
\hline $\mathrm{MI}[+14 \mathrm{~K},+15 \mathrm{~A}]$ & & & & & & & & & & & 0 & 0 \\
\hline $\mathrm{MI}[+14 \mathrm{R},+15 \mathrm{~A}]$ & & & & & & & & & & & 0 & 0 \\
\hline
\end{tabular}




\section{Discussion}

In the present work, we synthesized a series of variants of $\alpha$-conotoxins GI and MI and identified their inhibitory activity against muscular nAChRs as well as their toxicity in mice. Through the deletion of a Gly residue in loop2, we obtained a 3/4-subfamily $\alpha$-conotoxin GI[ $\Delta 8 \mathrm{G}]-\mathrm{II}$ which displayed $80 \%$ of wild-type GI's inhibitory activity against muscular nAChRs. In addition, GI[ $\Delta 8 \mathrm{G}]-\mathrm{II}$ exhibited medium toxicity, as $160 \mu \mathrm{g} / \mathrm{kg}$ could result in $80 \%$ mortality in mice (Table 3 ). GI[ $\Delta 8 \mathrm{G}]$-II is the shortest $\alpha$-conotoxin reported to date and it is the first reported 3/4-subfamily $\alpha$-conotoxin that can potently inhibit muscular nAChRs. Moreover, we found that the 3/6-subfamily $\alpha$-conotoxins GI[+13A], $\mathrm{GI}[+13 \mathrm{~K}]$, and GI[+13R] displayed similar potency toward muscular nAChRs as wild-type GI. This is also the first report of 3/6-subfamily $\alpha$-conotoxins with high inhibitory activity toward muscular nAChRs and high toxicity.

A surprising finding of this report is that the linear peptide GI $[\Delta 8 \mathrm{G}]$, formed after deletion of a Gly residue in loop2 of wild-type GI, forms the disulfide bond connectivity "1-4, 2-3" instead of the disulfide bond connectivity "1-3, 2-4" found in wild-type GI. Furthermore, the disulfide bond isomer (GI[ $\Delta 8 \mathrm{G}]-\mathrm{II})$ exhibited four-fold higher potency than the disulfide bond isomer (GI[ $\Delta 8 \mathrm{G}]-\mathrm{I})$ (Table 1$)$. This phenomenon is unique in $\alpha$-conotoxins targeting muscular nAChRs [40] and did not occur for the 3/4-subfamily MI variant and wild-type GI or MI. The linear peptide MI[ $\Delta 9 \mathrm{G}]$ forms a disulfide bond connectivity "1-3, 2-4" (the same as that of wild-type MI) and displayed low potency. We also determined the disulfide bond connectivity of the 3/6-, 3/7-subfamily GI and MI variants and found that they possess the disulfide bond connectivity " $\mathrm{C} 1-\mathrm{C} 3, \mathrm{C} 2-\mathrm{C} 4$ ", the same as in wild-type GI and MI. These results suggest that the disulfide bond connectivity is easily affected in the rigid 3/4-subfamily $\alpha$-conotoxins and that the disulfide bonds significantly impact variants' function.

It was also found that the extension of loop2 of GI and MI is limited to six amino acids. With six amino acids, the 3/6-subfamily variants exhibited obvious inhibitory activity, and the addition of the basic amino acid Arg or Lys in loop2 could further elevate their potency. However, seven amino acids resulted in loss of potency. despite the addition of basic amino acids, as demonstrated by the inhibitory activities of the 3/7-subfamily variants $\mathrm{GI}[+13 \mathrm{G},+14 \mathrm{G}], \mathrm{GI}[+13 \mathrm{~K},+14 \mathrm{~A}], \mathrm{GI}[+13 \mathrm{~A},+14 \mathrm{~K}], \mathrm{MI}[+14 \mathrm{~K},+15 \mathrm{~A}]$, and $\mathrm{MI}[+14 \mathrm{R}$, $+15 \mathrm{~A}]$. This could be attributed to an increase in flexibility, which resulted in a decreased binding of $\alpha$-conotoxin to nAChRs. Correspondingly, the CD spectra also showed that a random coil structure exists in the $3 / 7$-subfamily $\alpha$-conotoxins.

It should be noted that the toxicity of the GI and MI variants did not completely correspond to their inhibitory activity. For example, the 3/4- and 3/6-subfamily GI variants $\mathrm{GI}[\Delta 8 \mathrm{G}], \mathrm{GI}[+13 \mathrm{~A}]$, and GI[+13K] showed similar inhibitory activities as wild-type GI (Figure 4, Table 1), and the 3/6-subfamily MI[+14R] appeared to be even more active than $\mathrm{GI}\left(\mathrm{IC}_{50}=22.2 \mathrm{nM}\right)($ Table 1$)$, but their toxicities were significantly lower that of wild-type GI. In fact, $80 \mu \mathrm{g} / \mathrm{kg}$ or a higher dose was required to produce obvious death in mice, a two-fold lower potency than expected. In order to interpret these results, we performed kinetics analyses. The results showed that the recovery rates of GI[ $\Delta 8 \mathrm{G}]-\mathrm{II}$ and GI[+13A] were significantly higher than that of GI (Table 2), which may explain the low toxicity. For $\mathrm{MI}[+14 \mathrm{R}]$, the on-rate and off-rate kinetics could not explain its low toxicity. The binding sites of the GI and MI variants may be partially different from that of wild-type GI or MI.

In summary, we produced 3/4-subfamily $\alpha$-conotoxins with the disulfide bond connectivity " $\mathrm{C} 1-\mathrm{C} 4, \mathrm{C} 2-\mathrm{C} 3$ " and a series of $3 / 6$-subfamily $\alpha$-conotoxins by the modifications of loop2 of GI and MI. They displayed potent inhibitory activities toward muscular nAChRs and low toxicity in mice. These shortest and larger $\alpha$-conotoxins, as regards loop2, expand our knowledge of $\alpha$-conotoxins, providing new motifs for further modifications of $\alpha$-conotoxins. 


\section{Materials and Methods}

\subsection{Materials, Reagents, and Animals}

Rink resin was obtained from Tianjin Nankai Hecheng S\&T Company. N-Fmoc-amino acids, 1-hydroxybenzotriazole (HOBt), 2-(1H-benzotriazole-1-yl)-1,1,3,3-tetramethyluronium hexafluorophosphate (HBTU), $\mathrm{N}, \mathrm{N}$-diisopropyl ethylamine (DIEA), and TFA were purchased from GL Biochem Ltd. (Shanghai, China). DTT was obtained from Beijing Yinuokai Technology Co., Ltd. (Beijing, China). TIPS; TFA was purchased from Beijing Coupling Technology Co., Ltd. (Beijing, China). Iodine and ascorbic acid were purchased from Chemical Reagent Co., and Ltd. (Beijing, China). Acetonitrile was from fisher chemical. Muscular nAChRs receptor plasmids were from Addgene Company (Watertown, MA, USA).

Kunming mice (18-22 g, 3-4 weeks old) were obtained from SPF (Beijing, China) Biotechnology Co., Ltd., and housed at $23 \pm 2{ }^{\circ} \mathrm{C}$ with a relative humidity of $50 \%$ under a $12 \mathrm{~h}$ light/dark cycle. Food pellets and water were available ad libitum. Female Xenopus laevis frogs (Cat. No. 20170127, 100-150 g, 24-36 months old) were obtained from the Research Center for Eco-Environmental Sciences (Beijing, China). All experiments were conducted in accordance with the guidelines of the Animal Research Advisory Committee of Beijing Institutes for Biological Science and conformed to the European Community directives for the care and use of laboratory animals.

\subsection{Peptide Synthesis and Folding}

Peptides with protecting groups were synthesized using a Sophas peptide synthesizer (Zinsser Analytic, Frankfurt, Germany) by the Standard Fmoc method and then cleaved from the Rink resin $(0.05 \mathrm{mmol})$ in a mixed solution $(4.4 \mathrm{~mL}$ TFA, $0.25 \mathrm{~mL}$ water, $0.25 \mathrm{~g}$ DTT, $0.1 \mathrm{~mL}$ triisopropylsilane). The resulting linear peptide was folded in $0.1 \mathrm{M}$ ammonium acetate $(\mathrm{pH} 8.0-8.20)$ for $24-48 \mathrm{~h}$. The folding progress was detected by C18 HPLC. After the folding was completed, the $\mathrm{pH}$ was adjusted to $4-5$ with acetic acid to terminate the reaction, and then the folding liquid was desalted and loaded on a Nucleosil $25 \times 250 \mathrm{~mm}$ preparative C18 column using a preparative HPLC pump (Waters Delta Prep 4000, Waters, Milford, CT, USA). The reversed-phase column was washed with $95 \%$ acetonitrile containing $0.1 \%$ TFA at a flow rate of $3.0 \mathrm{~mL} / \mathrm{min}$. The resulting peptide was further purified by semi-preparative reversed-phase HPLC using a $10 \times 250 \mathrm{~mm}$ Kromasil C18 column. After lyophilization, the purity of the peptide was assessed by analytical reversed-phase HPLC using an Agilent Eclipse Plus $C_{18}$ column $(5 \mu \mathrm{m}, 100 \AA$, $4.6 \times 250 \mathrm{~mm})$ with a 25 min linear gradient of $10-50 \%$ buffer B $(0.1 \%$ TFA in acetonitrile) at a flow rate of $1 \mathrm{~mL} / \mathrm{min}$. The purity of all final products was $\geq 95 \%$. The concentration of the peptides was determined by UV absorbance and a theoretically calculated molar extinction coefficient $\varepsilon(280 \mathrm{~nm})$ of $1490 \mathrm{~mol} / \mathrm{L}^{-1} \mathrm{~cm}^{-1}$ based on the number of tyrosine (Tyr) residues (all peptides tested contain Tyr) [40].

The GI and MI variants that could not correctly form from one-step folding were synthesized with a two-step method described below (determination of disulfide bond connectivity).

\subsection{Determination of Disulfide Bond Connectivity}

The disulfide connectivity of the one-step oxidative-folding products of GI and MI variants was determined as described previously [41,42]. Briefly, linear peptides containing an acetamidomethyl (Acm)-protecting group at the $\mathrm{C} 2-\mathrm{C} 4$ or $\mathrm{C} 1-\mathrm{C} 4$ position were synthesized and then folded by incubation in $0.1 \mathrm{M} \mathrm{NH}_{4} \mathrm{HCO}_{3}(\mathrm{pH} \mathrm{8.0)}$ ) at room temperature for 24-72 $\mathrm{h}$. The folded products were further oxidized with an iodine mixture containing $30 \% \mathrm{CH}_{3} \mathrm{CN} / 2 \% \mathrm{TFA} / 68 \% \mathrm{H}_{2} \mathrm{O}$ for 10 min to yield peptides with-S-S- bridges at " $\mathrm{C} 1-\mathrm{C} 3$, $\mathrm{C} 2-\mathrm{C} 4$ " or "C1-C4, C2-C3". The mixture of this second oxidized product and the one-step folding product of GI or MI variants was analyzed by HPLC: one peak represented a one-step folding product possessing the known disulfide connectivity. 


\subsection{Circular Dichroism (CD) Spectra}

A Chirasscan plus spectrometer (Applied Optophysics, London, UK) was used to determine the secondary structure of the GI and MI variants. Each toxin was diluted with $10 \mathrm{mM}$ phosphate buffer $(\mathrm{pH}=7.2)$ to a concentration of $35 \mu \mathrm{M}$. The test conditions were: wavelength of 190-260 nm, scanning rate of $60 \mathrm{~nm} / \mathrm{s}$, sample cell path length of $1 \mathrm{~mm}$, 3 repeats.

\subsection{Oocyte Two-Electrode Voltage Clamp}

Rat muscular nAChRs $\alpha 1$ [L9S] [43], $\beta 1, \delta$, and $\varepsilon$ plasmids were purchased from Addgene. The $\alpha 1$ plasmid was corrected to normal $\alpha 1$ by PCR. The expression of $n A C h R$ subunits in Xenopus oocyte and electrophysiological tests were performed as described previously $[18,36,44]$. Briefly, each oocyte was injected with 45-55 ng cRNA $(1000 \mathrm{ng} / \mu \mathrm{L})$ of $\alpha 1, \beta 1, \delta$, and $\varepsilon$ at a ratio of 2:1:1:1. Then it was incubated in ND96 solution $(96.0 \mathrm{mM}$ $\mathrm{NaCl}, 2.0 \mathrm{mM} \mathrm{KCl}, 1.8 \mathrm{mM} \mathrm{CaCl}_{2}, 1.0 \mathrm{mM} \mathrm{MgCl}_{2}$, and 5 mM HEPES; $\mathrm{pH}$ 7.1-7.3) containing $2.5 \mathrm{mM}$ pyruvic acid sodium, $0.1 \mathrm{mg} / \mathrm{mL}$ BSA, and antibiotics $(10 \mathrm{U} / \mathrm{mL}$ penicillin, $10 \mu \mathrm{g} / \mathrm{mL}$ streptomycin) (Gibco by Life Technologies, Grand Island, NY, USA) at $18^{\circ} \mathrm{C}$. Electrophysiological recordings were performed $2-5$ days post-injection at $22{ }^{\circ} \mathrm{C}$. The oocyte was exposed to the ACh pulse for $3 \mathrm{~s}$ every $5 \mathrm{~min}$; the concentration of ACh was $200 \mu \mathrm{M}$. The membrane potential was clamped at $-70 \mathrm{mV}$, and the ACh-gated currents were recorded with a two-electrode voltage-clamp amplifier Axoclamp 900A (Axon Instruments Inc., UnionCity, CA, USA). In high-dose experiments ( $1 \mu \mathrm{M}$ or greater), $5.5 \mu \mathrm{L}$ of a 10-fold concentrated conotoxin solution was directly pipetted into a static bath $5 \mathrm{~min}$ before the ACh pulse was exposed.

In the on-rate and off-rate kinetics for GI, MI, and their variants' inhibition of the muscular receptor subtype, the gravity-driven perfusion of oocytes with ND96A was performed at a rate of $2 \mathrm{~mL} / \mathrm{min}$. Once a stable baseline was achieved, the cells were continuously perfused with conotoxin dissolved in ND96 solution and pulsed with ACh for $3 \mathrm{~s}$ at $2 \mathrm{~min}$ intervals. The association and dissociation rate constants were calculated from a single-exponential equation $\left(Y=Y_{\max } \times\left(\exp \left(-k_{o f f} \times \mathrm{t}\right)\right)\right.$ for dissociation and from the equation $Y=Y_{\max } \times\left(1-\exp \left(-k_{\text {obs }} \times t\right)\right.$ for association, where $Y_{\max }$ is the bound ligand at equilibrium. The dose-response data were fit to the equation: $\%$ response $=100 /\left[1+\left([\right.\right.$ toxin $\left.\left.] / \mathrm{IC}_{50}\right) \mathrm{n}\right]$, where $\mathrm{n}$ is the Hill coefficient, and $\mathrm{IC}_{50}$ is the antagonist concentration giving half-maximal response, by nonlinear regression analysis using GraphPad Prism (GraphPad Software, San Diego, CA, USA).

\subsection{Toxicity Tests}

Mice were randomly divided into groups treated with the GI or MI variants and a control group treated with wild-type GI or MI; 10 mice were included in each group, half of them males, and half of them females. We intraperitoneally injected into the mice $200 \mu \mathrm{L}$ of saline solution containing different amounts of toxins. The time to death of each mouse and the number of deaths were recorded in $24 \mathrm{~h}$. The time to death was expressed as the average value \pm standard deviation.

Author Contributions: X.M. and Q.H. contributed equally to this work. Investigation, methodology and writing-original draft preparation, X.M. and Q.H.; investigation, S.Y., S.X., Y.H., Z.Z. and X.X.; formal analysis, X.X.; conceptualization, project administration, supervision and writing-review and editing, Q.D. All authors have read and agreed to the published version of the manuscript.

Funding: This work was funded by the National Key Research and Development Project of China (2019YFC0312605).

Institutional Review Board Statement: The study was conducted according to the guidelines of the Declaration of Animal Research Advisory Committee in Beijing Institutes for Biological Science and was approved by the Institutional Review Board of Beijing Institutes of Biotechnology (protocol code 2021-011 and 28 February 2021).

Informed Consent Statement: Not applicable. 
Conflicts of Interest: The authors declare no conflict of interest.

\section{References}

1. Albuquerque, E.X.; Pereira, E.F.; Alkondon, M.; Rogers, S.W. Mammalian nicotinic acetylcholine receptors: From structure to function. Physiol. Rev. 2009, 89, 73-120. [CrossRef]

2. Zoli, M.; Pucci, S.; Vilella, A.; Gotti, C. Neuronal and extraneuronal nicotinic acetylcholine receptors. Curr. Neuropharmacol. 2018, 16, 338-349. [CrossRef]

3. Wonnacott, S.; Bermudez, I.; Millar, N.S.; Tzartos, S.J. Nicotinic acetylcholine receptors. Br. J. Pharmacol. 2018, 175, 1785-1788. [CrossRef]

4. Bertrand, D.; Terry, A.V., Jr. The wonderland of neuronal nicotinic acetylcholine receptors. Biochem. Pharmacol. 2018, 151, 214-225. [CrossRef] [PubMed]

5. Cisterna, B.A.; Vargas, A.A.; Puebla, C.; Fernández, P.; Escamilla, R.; Lagos, C.F.; Matus, M.F.; Vilos, C.; Cea, L.A.; Barnafi, E.; et al. Active acetylcholine receptors prevent the atrophy of skeletal muscles and favor reinnervation. Nat. Commun. 2020, 11, 1073. [CrossRef]

6. Becchetti, A.; Aracri, P.; Meneghini, S.; Brusco, S.; Amadeo, A. The role of nicotinic acetylcholine receptors in autosomal dominant nocturnal frontal lobe epilepsy. Front. Physiol. 2015, 6, 22. [CrossRef] [PubMed]

7. Ved, H.S.; Doshi, G.M. A review on emerging drug targets in treatment of Schizophrenia. Curr. Drug Targets 2020, 21, 1593-1605. [CrossRef]

8. Hone, A.J.; McIntosh, J.M. Nicotinic acetylcholine receptors in neuropathic and inflammatory pain. FEBS Lett. 2018, 592, 1045-1062. [CrossRef] [PubMed]

9. Lebbe, E.K.; Peigneur, S.; Wijesekara, I.; Tytgat, J. Conotoxins targeting nicotinic acetylcholine receptors: An overview. Mar. Drugs 2014, 12, 2970-3004. [CrossRef] [PubMed]

10. Jin, A.H.; Muttenthaler, M.; Dutertre, S.; Himaya, S.W.A.; Kaas, Q.; Craik, D.J.; Lewis, R.J.; Alewood, P.F. Conotoxins: Chemistry and biology. Chem. Rev. 2019, 119, 11510-11549. [CrossRef]

11. Turner, M.W.; Marquart, L.A.; Phillips, P.D.; McDougal, O.M. Mutagenesis of $\alpha$-conotoxins for enhancing activity and selectivity for nicotinic acetylcholine receptors. Toxins 2019, 11, 113. [CrossRef]

12. Robinson, S.D.; Norton, R.S. Conotoxin gene superfamilies. Mar. Drugs 2014, 12, 6058-6101. [CrossRef]

13. Wu, R.J.; Wang, L.; Xiang, H. The structural features of $\alpha$-conotoxin specifically target different isoforms of nicotinic acetylcholine receptors. Curr. Top. Med. Chem. 2015, 16, 156-169. [CrossRef] [PubMed]

14. Kennedy, A.C.; Belgi, A.; Husselbee, B.W.; Spanswick, D.; Norton, R.S.; Robinson, A.J. $\alpha$-Conotoxin peptidomimetics: Probing the minimal binding motif for effective analgesia. Toxins 2020, 12, 505. [CrossRef]

15. Li, X.; Tae, H.S.; Chu, Y.; Jiang, T.; Adams, D.J.; Yu, R. Medicinal chemistry, pharmacology, and therapeutic potential of $\alpha$-conotoxins antagonizing the $\alpha 9 \alpha 10$ nicotinic acetylcholine receptor. Pharmacol. Ther. 2021, 222, 107792. [CrossRef] [PubMed]

16. Gray, W.R.; Luque, F.A.; Galyean, R.; Atherton, E.; Sheppard, R.C.; Stone, B.L.; Reyes, A.; Alford, J.; McIntosh, M.; Olivera, B.M.; et al. Conotoxin GI: Disulfide bridges, synthesis, and preparation of iodinated derivatives. Biochemistry 1984, 23, 2796-2802. [CrossRef] [PubMed]

17. Hann, R.M.; Pagán, O.R.; Gregory, L.M.; Jácome, T.; Eterović, V.A. The 9-arginine residue of alpha-conotoxin GI is responsible for its selective high affinity for the alphagamma agonist site on the electric organ acetylcholine receptor. Biochemistry 1997, 36, 9051-9056. [CrossRef] [PubMed]

18. Ning, J.; Li, R.; Ren, J.; Zhangsun, D.; Zhu, X.; Wu, Y.; Luo, S. Alanine-scanning mutagenesis of $\alpha$-conotoxin GI reveals the residues crucial for activity at the muscle acetylcholine receptor. Mar. Drugs 2018, 16, 507. [CrossRef] [PubMed]

19. Tae, H.S.; Gao, B.; Jin, A.H.; Alewood, P.F.; Adams, D.J. Globular and ribbon isomers of Conus geographus $\alpha$-conotoxins antagonize human nicotinic acetylcholine receptors. Biochem. Pharmacol. 2021, 190, 114638. [CrossRef]

20. Gray, W.R.; Rivier, J.E.; Galyean, R.; Cruz, L.J.; Olivera, B.M. Conotoxin MI. disulfide bonding and conformational states. J. Biol. Chem. 1983, 258, 12247-12251. [CrossRef]

21. Papineni, R.V.; Sanchez, J.U.; Baksi, K.; Willcockson, I.U.; Pedersen, S.E. Site-specific charge interactions of alpha-conotoxin MI with the nicotinic acetylcholine receptor. J. Biol. Chem. 2001, 276, 23589-23598. [CrossRef]

22. Gray, W.R.; Luque, A.; Olivera, B.M.; Barrett, J.; Cruz, L.J. Peptide toxins from Conus geographus venom. J. Biol. Chem. 1981, 256, 4734-4740. [CrossRef]

23. Myers, R.A.; Zafaralla, G.C.; Gray, W.R.; Abbott, J.; Cruz, L.J.; Olivera, B.M. Alpha-conotoxins, small peptide probes of nicotinic acetylcholine receptors. Biochemistry 1991, 30, 9370-9377. [CrossRef] [PubMed]

24. Groebe, D.R.; Gray, W.R.; Abramson, S.N. Determinants involved in the affinity of alpha-conotoxins GI and SI for the muscle subtype of nicotinic acetylcholine receptors. Biochemistry 1997, 36, 6469-6474. [CrossRef]

25. Benie, A.J.; Whitford, D.; Hargittai, B.; Barany, G.; Janes, R.W. Solution structure of alpha-conotoxin SI. FEBS Lett. 2000, 476, 287-295. [CrossRef]

26. Favreau, P.; Krimm, I.; Le-Gall, F.; Bobenrieth, M.J.; Lamthanh, H.; Bouet, F.; Servent, D.; Molgo, J.; Ménez, A.; Letourneux, Y.; et al. Biochemical characterization and nuclear magnetic resonance structure of novel alpha-conotoxins isolated from the venom of Conus consors. Biochemistry 1999, 38, 6317-6326. [CrossRef] 
27. Giribaldi, J.; Wilson, D.; Nicke, A.; El-Hamdaoui, Y.; Laconde, G.; Faucherre, A.; Moha-Ou-Maati, H.; Daly, N.L.; Enjalbal, C.; Dutertre, $\mathrm{S}$. Synthesis, structure and biological activity of CIA and CIB, two $\alpha$-conotoxins from the predation-evoked venom of Conus catus. Toxins 2018, 10, 222. [CrossRef]

28. Peigneur, S.; Devi, P.; Seldeslachts, A.; Ravichandran, S.; Quinton, L.; Tytgat, J. Structure-function elucidation of a new $\alpha$-conotoxin, MilIA, from Conus milneedwardsi. Mar. Drugs 2019, 17, 535. [CrossRef]

29. Martinez, J.S.; Olivera, B.M.; Gray, W.R.; Craig, A.G.; Groebe, D.R.; Abramson, S.N.; McIntosh, J.M. Alpha-conotoxin EI, a new nicotinic acetylcholine receptor antagonist with novel selectivity. Biochemistry 1995, 34, 14519-14526. [CrossRef]

30. Han, K.H.; Hwang, K.J.; Kim, S.M.; Kim, S.K.; Gray, W.R.; Olivera, B.M.; Rivier, J.; Shon, K.J. NMR structure determination of a novel conotoxin, [Pro 7,13] alpha-conotoxin PIVA. Biochemistry 1997, 36, 1669-1677. [CrossRef] [PubMed]

31. Teichert, R.W.; Rivier, J.; Dykert, J.; Cervini, L.; Gulyas, J.; Bulaj, G.; Ellison, M.; Olivera, B.M. Alpha-conotoxin OIVA defines a new alpha-conotoxin subfamily of nicotinic acetylcholine receptor inhibitors. Toxicon 2004, 44, 207-214. [CrossRef] [PubMed]

32. Teichert, R.W.; Rivier, J.; Torres, J.; Dykert, J.; Miller, C.; Olivera, B.M. A uniquely selective inhibitor of the mammalian fetal neuromuscular nicotinic acetylcholine receptor. J. Neurosci. 2005, 25, 732-736. [CrossRef]

33. López-Vera, E.; Jacobsen, R.B.; Ellison, M.; Olivera, B.M.; Teichert, R.W. A novel alpha conotoxin (alpha-PIB) isolated from C. purpurascens is selective for skeletal muscle nicotinic acetylcholine receptors. Toxicon 2007, 49, 1193-1199. [CrossRef]

34. Chi, S.W.; Park, K.H.; Suk, J.E.; Olivera, B.M.; McIntosh, J.M.; Han, K.H. Solution conformation of alpha-conotoxin EIVA, a potent neuromuscular nicotinic acetylcholine receptor antagonist from Conus ermineus. J. Biol. Chem. 2003, 278, 42208-42213. [CrossRef]

35. Quinton, L.; Servent, D.; Girard, E.; Molgó, J.; Le-Caer, J.P.; Malosse, C.; Haidarel, A.; Lecoq, A.; Gilles, N.; Chamot-Rooke, J. Identification and functional characterization of a novel $\alpha$-conotoxin (EIIA) from Conus ermineus. Anal. Bioanal. Chem. 2013, 405, 5341-5351. [CrossRef] [PubMed]

36. Hoggard, M.F.; Rodriguez, A.M.; Cano, H.; Clark, E.; Tae, H.S.; Adams, D.J.; Godenschwege, T.A.; Marí, F. In vivo and in vitro testing of native $\alpha$-conotoxins from the injected venom of Conus purpurascens. Neuropharmacology 2017, 127, 253-259. [CrossRef]

37. Rybin, M.J.; O’Brien, H.; Ramiro, I.B.L.; Azam, L.; McIntosh, J.M.; Olivera, B.M.; Safavi-Hemami, H.; Yoshikami, D. $\alpha$ M-conotoxin MIIIJ blocks nicotinic acetylcholine receptors at neuromuscular junctions of frog and fish. Toxins 2020, 12, 197. [CrossRef] [PubMed]

38. Maslennikov, I.V.; Sobol, A.G.; Gladky, K.V.; Lugovskoy, A.A.; Ostrovsky, A.G.; Tsetlin, V.I.; Ivanov, V.T.; Arseniev, A.S. Two distinct structures of alpha-conotoxin GI in aqueous solution. Eur. J. Biochem. 1998, 254, 238-247. [CrossRef]

39. Faragó, Z.; Mirzahosseini, A.; Horváth, D.; Pálla, T.; Horváth, P.; Perczel, A.; Noszál, B. Solution structure and acid-base properties of reduced $\alpha$-conotoxin MI. Chem. Biodivers. 2021, e2100464. [CrossRef]

40. He, Y.; Cheng, J.; Lu, H.; Li, J.; Hu, J.; Qi, Z.; Liu, Z.; Jiang, S.; Dai, Q. Potent HIV fusion inhibitors against Enfuvirtide-resistant HIV-1 strains. Proc. Natl. Acad. Sci. USA 2008, 105, 16332-16337. [CrossRef]

41. Wang, S.; Zhao, C.; Liu, Z.; Wang, X.; Liu, N.; Du, W.; Dai, Q. Structural and functional characterization of a novel $\alpha$-conotoxin Mr1.7 from Conus marmoreus targeting neuronal nAChR $\alpha 3 \beta 2, \alpha 9 \alpha 10$ and $\alpha 6 / \alpha 3 \beta 2 \beta 3$ subtypes. Mar. Drugs 2015, 13, 3259-3275. [CrossRef] [PubMed]

42. Chen, J.; Liang, L.; Ning, H.; Cai, F.; Liu, Z.; Zhang, L.; Zhou, L.; Dai, Q. Cloning, synthesis and functional characterization of a novel $\alpha$-conotoxin Lt1.3. Mar. Drugs 2018, 16, 112. [CrossRef] [PubMed]

43. Labarca, C.; Nowak, M.W.; Zhang, H.; Tang, L.; Deshpande, P.; Lester, H.A. Channel gating governed symmetrically by conserved leucine residues in the M2 domain of nicotinic receptors. Nature 1995, 376, 514-516. [CrossRef] [PubMed]

44. Cai, F.; Xu, N.; Liu, Z.; Ding, R.; Yu, S.; Dong, M.; Wang, S.; Shen, J.; Tae, H.S.; Adams, D.J.; et al. Targeting of N-type calcium channels via $\mathrm{GABA}_{\mathrm{B}}$-receptor activation by $\alpha$-conotoxin Vc1.1 variants displaying improved analgesic activity. J. Med. Chem. 2018, 61, 10198-10205. [CrossRef] [PubMed] 